\title{
Rachimedural Trauma: Epidemiology and Complications
}

Iraktania Vitorino Diniz', Karen Krystine Gonçalves de Brito², Elizabeth Souza Silva de Aguiar ${ }^{2}$, Mirian Alves da Silva ${ }^{7}$ Alana Tamar Oliveira de Sousa ${ }^{3}$, Suellen Duarte de Oliveira Matos', Smalyanna Sgren da Costa Andrade 2 , Celio Maroja Di Pace Neto 4 , Arthur Vitorino Di Pace ${ }^{5}$, Irany Vitorino Correa De Toledo6, Emanuelle Malzac Freire de Santana ${ }^{1}$, Simone Helena dos Santos Oliveira7, Marta Miriam Lopes Costa7, Maria Julia Guimarães de Oliveira Soares ${ }^{7}$

\section{Abstract}

Background: Traumatic spinal cord is a public health problem due to the high morbidity and mortality worldwide. The objective of this research was to characterize the profile demographic and clinical partner of people with TRM; analyze correlations between clinical features of traumatic injury level and its complications.

Methods: Observational study, the cut cross-sectional with a quantitative approach, performed with 80 people with TRM. Data were analyzed using descriptive and inferential techniques statistics.

Results: The results show correlation of spinal cord injury in lumbar level with accidents with firearms, of chest injury to car accidents and cervical injuries the diving in shallow water. Regarding complications, quadriplegia had greater influence as a risk factor for UP, spasticity, orthostatic hypotension, urinary complications, autonomic dysreflexia and intestinal disorders in relation to paraplegia, but showed a protective factor to pain syndromes.

Conclusion: The absence of notification is a limiting factor for research and construction of new public policies aimed at preventing determinants external causes of TRM, as well as development of actions aimed at specialized care to minimize complications and improve quality of life in this population.
1 Masters student in the Graduate Program in Nursing at the Federal University of Paraíba, João Pessoa, Paraíba, Brazil.

2 Doctoral student in the Graduate Program in Nursing at the Federal University of Paraíba, João Pessoa, Paraíba, Brazil.

3 Doctor in Nursing. Associate professor at Federal University of Campina Grande, Cuité, Paraíba, Brazil.

4 Surgeon Dentist Specialized in Orthodontics at the Core for Studies and Dental Improvement. João Pessoa, Paraiba, Brazil.

5 Graduate Student in Psychology at an University Center, João Pessoa, Paraiba, Brazil.

6 Dermatology Nurse, Coordinator of the Hospital Clementino Fraga; Dermatology Commission, Joao Pessoa, Paraiba, Brazil.

7 PhD in Nursing. Associate professor at Federal University of Paraíba. João Pessoa, Paraíba, Brazil.

\section{Contact information:}

\section{Iraktania Vitorino Diniz.}

Address: Oceano Atlantico, no 254, ap 303. CEP: 58102-252. Intermares, Cabedelo. Paraíba.

Tel: +55 83996941923 .

”iraktania@hotmail.com

Keywords

Spinal column; Complications; Epidemiology; External Causes. 


\section{Introduction}

The rachimedural trauma (TRM) is defined as any injury that primarily affects the spine, including whether or not the spinal cord or nerve roots, in any of its segments, which can lead to motor, sensory, autonomic and psychoaffective disorders, temporarily or permanently, complete or incomplete [12]. These transformations are manifested mainly as paralysis or paresis of members, change in muscle tone, alteration of surface and deep reflexes, alteration or loss of different sensitivities (tactile, painful, vibratory, by pressure and proprioceptive), sexual dysfunction, and autonomic changes as vasoplegia, alteration of sweating, loss of bladder and bowel control, among other [1].

According to the American Spinal Injury Association (ASIA), the classification of spinal cord injury which is defined as the standard method for evaluating the neurological status of individuals with TRM. It is divided into five levels, namely: complete lesion, without motor and sensory preservation - ASIA A, incomplete injury - ASIA B, although it is incomplete, there is loss of motor function, but it keeps the sensory function, which does not occur with ASIA C and D, in which the person does not lose motor function and they differ from each other with regard to the degree of force and normal/without injury - ASIA E. This specification uses as a parameter the degree of lesion involvement [3].

TRM represents a public health problem, given its high morbidity and mortality in the world's population, in addition to the functional repercussion and individual and social costs associated with installed deficiencies [4].

Additional to the exposed aspects, it should be noted that this is a reportable disease, and findings concerning the quantitative about the real situational diagnosis of Brazil are rare.

Studies estimate a worldwide incidence of TRM between 9 and 50 cases/million inhabitants, with involvement primarily in major urban centers [5-6].
In Brazil, there are about 6,000 to 8,000 new cases of TRM per year [1], being spent on average of $R \$ 9$ billion per year for the trauma care [5]. The etiology of trauma is among traffic accidents, accidents with firearms, falls from height, diving into shallow water and aggressions [7, 2].

In a convergent manner to current paradigms, it is understood that epidemiological studies related to traumatic spinal cord injuries are important because of the impact that these cause to the individual, in the psychological, personal and biological, or economic and social, levels.

Given the above, it substantiates that the epidemiological knowledge regarding TRM can provide subsidies for the development of prevention programs, etiological factors of TRM and improvement in primary care [2]. Therefore, the current study aimed to: characterize the socio-demographic and clinical-epidemiological profile of people with TRM; and analyze correlations between clinical characteristics, level of injury and complications in the person with TRM.

\section{Method}

This is an observational and cohort-cross study, with a quantitative approach, performed with the population of individuals with TRM registered in four associations, three rehabilitation centers and three public hospitals in the city of João Pessoa/Paraíba/ Brazil, totaling 10 institutions.

From the incidence estimate for the TRM extracted based on scientific literature, which identifies the occurrence of 10,000 new cases of TRM each year in Brazil, with an incidence of $5.38 \%$ [8], a statistical sample calculation was performed. The sample size was calculated based on a $5 \%$ margin of error (Error $=0.05)$ with $\alpha=0.05(Z 0.025=1.96)$ and considering as exposed population 723,514 individuals residing in João Pessoa/Paraíba/Brazil [9]. So it is configured that at least 79 people should be interviewed within the period reserved for data 
collection, so that the sample presented statistical significance.

The sample consisted of 80 participants who met the inclusion criteria of being more than 18 years old. The exclusion criterion used was the variation of cognitive state, in the case where it prevents the interview. The criterion of discontinuity was the waiver to participate in the study after collecting data, which did not happen to any participant.

The data collection instrument consists of an interview form with questions involving the sociodemographic and clinical characterization of individuals with TRM. For its construction, observations and evaluations carried out by one of the researchers were used as reference, based on what is in international and national guidelines [10-12], which was verified by specialists and subject to the achievement of pre-test with twenty (20) patients, randomly selected. Participants in the pilot test were not included in the sample.

The operational structure used for data collection was a convenience sampling, i.e., the individuals interviewed were selected based on their presence in the institutions between May and November 2014. When conducted in institutions, the interviews took place in a reserved manner, in individual rooms, while the other interviews occurred at home. This contact was generated by network, that is, customers or professionals themselves informed about people with TRM, who were not attending the institutions. In this way, we made telephone contact with these people, who were previously informed about the research and asked about their availability of participation. After their acceptance, the convenient day and time for the visit was scheduled.

After collection, the data were collected, stored and analyzed using the Statistical Package for Social Science (SPSS) statistical program, version 20.0, being applied descriptive statistics techniques with absolute numbers, percentages; it was used for characterization of the research subjects and inferential statistics for correspondence analysis, to verify mul- tivariate association between the causes of trauma, level of injury and trauma sequelae. The Chi-square test and Relative Risk were used in order to verify and magnitude of this association between sequel and the complications of spinal cord injury. It was considered the significance level of $95 \%$. It should be noted that for relative risk classification cutoff point was used as the following classification: 1-1.2 trivial risk; 1.2-1.9 small risk; 1.9-3.0 moderate risk; 3.0-5.7 great risk; $>5.7$ risk [13].

It is remarkable that the research was approved by the Research Ethics Committee of the University Hospital Lauro Wanderley (HULW), under protocol number 423/2011 and CAAE N 0058.0.462.126-11, in compliance with the requirements of Resolution 196/96, revoked by 466/12 of the National Health Council [14] and Resolution 311/2007 of the Federal Council of Nursing.

\section{Results}

The sample was constituted by 80 patients of both genders, aged between 18 and 89 years (Average $36.23 \pm 13,81 \mathrm{DP})$. There was a predominance of individuals in economically active range of 21-40 years old (65.1\%), being $59(73.8 \%)$ male, single and/or married - both with 36 (45\%) - without children 29 (36.3\%). As for education, 64 (80\%) individuals had more than four (4) years of study and basic monthly income of 1 to 3 minimum wages, 58 of them (72.5\%).

Regarding clinical aspects, 45 (56.3\%) individuals presented predominantly thoracic injury followed by 20 (25\%) back injury. Etiologically, the traffic accidents stood out, being 29 (36.3\%), followed by firearms, 25 (31.3\%). Relative to the trauma sequel, most had complete paraplegia - 45 (56.3\%) - followed by incomplete paraplegia - 25 (31.3\%).

Regard to multivariate associations between the cause of the trauma and the level of spinal cord injury, it was observed that injuries by firearms were related to lower back trauma, while cervical lesions 
Figure 1: Representation of the cause of trauma and level of spinal cord injury in two-dimensional plane. João Pessoa/PB, 2014.

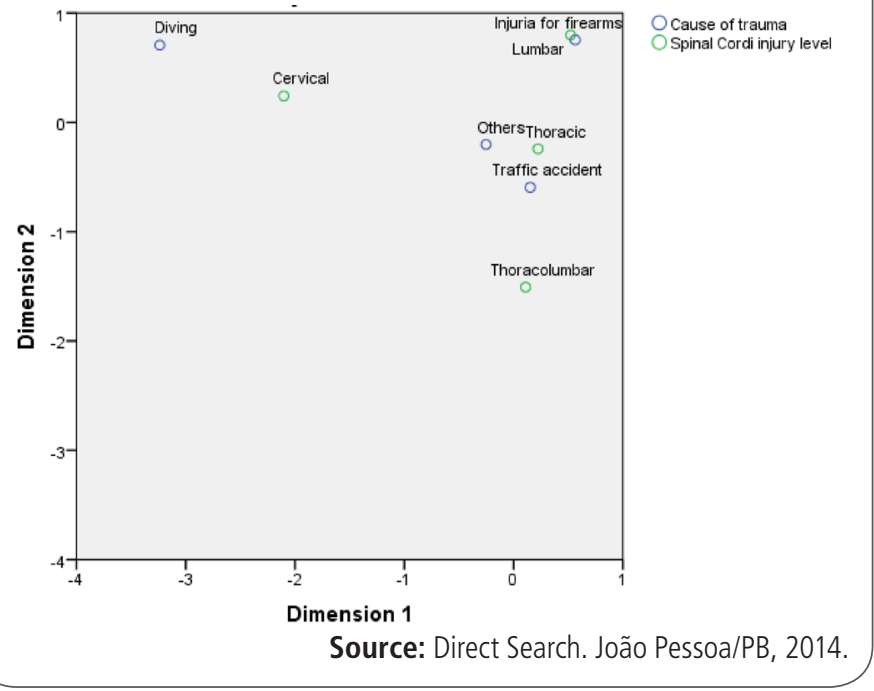

Figure 2: Representation of the cause of trauma and type of sequel to the two-dimensional plane. João Pessoa/PB, 2014.

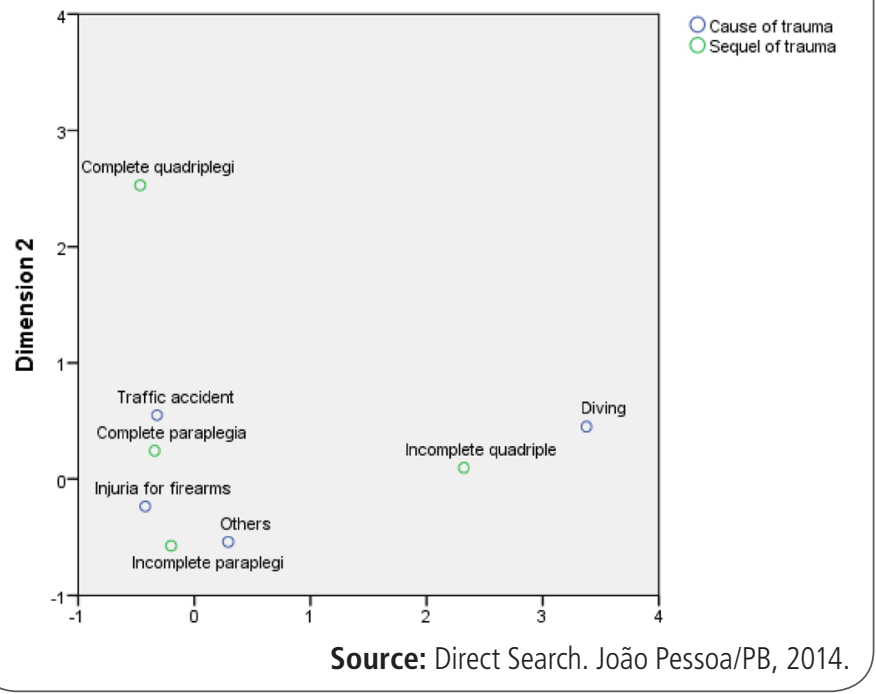

corresponded to diving and traffic accidents, which had closer ties with thoracic lesions (Figure 1).

The correlation between the cause of trauma and sequelae presented was demonstrated by means of two-dimensional correlation analysis: road accidents with complete paraplegia; injury by firearm with complete and incomplete paraplegia; and diving with incomplete quadriplegia. (Figure 2)

Given the known morbidity and mortality related to TRM, the main complications presented and their association with the generated sequels were investigated within the sample.

For categorization of the relative risk, the most frequent complications in patients with spinal cord injury were first described, as Table 1.

In the relative risk analysis, it appears that quadriplegia increases the risk of complications in the TRM, except for pain syndromes, to which it presents a protection factor. Correspondingly, the association between the level of spinal cord injury (cervical (quadriplegia) or thoracic or lumbar injury (paraplegia), it is perceived increased risk of all complications, except for pain syndromes for which it is a protection factor (Table 2 ).

Table 1. Prevalence of complications associated with spinal cord injury $(n=80)$. João Pessoa/PB, 2014

\begin{tabular}{|l|c|c|}
\hline \multicolumn{1}{|c|}{ Type of Complication } & N & $\%$ \\
\hline Urinary complications & 76 & 96.2 \\
\hline Pressure ulcer & 60 & 75.9 \\
\hline Spasticity & 50 & 62.5 \\
\hline Painful syndrome & 43 & 54.4 \\
\hline Intestinal disorders & 43 & 54.4 \\
\hline Orthostatic hypotension & 23 & 29.1 \\
\hline Autonomic dysreflexia & 20 & 25.3 \\
\hline \multicolumn{2}{|c|}{ Source: Direct Search. João Pessoa/PB, 2014 } \\
\hline
\end{tabular}

Table 2. Association between type of sequel (paraplegic/quadriplegic) and complications of TRM ( $\mathrm{n}=80)$. João Pessoa/PB, 2014.

\begin{tabular}{|l|c|c|}
\hline \multirow{2}{*}{ Type of Complication } & \multicolumn{2}{|c}{$\begin{array}{c}\text { Type of sequel } \\
\text { (tetraplegic/paraplegic) }\end{array}$} \\
\cline { 2 - 3 } & RR & IC (95\%) \\
\hline Pressure ulcer & 1.027 & $0.707-1.493$ \\
\hline Spasticity & 1.266 & $0.853-1.880$ \\
\hline Orthostatic hypotension & 2.160 & $1.065-1.382$ \\
\hline Painful syndrome & 0.583 & $0.227-1.502$ \\
\hline Urinary complications & 1.045 & $0.994-1.098$ \\
\hline Autonomic dysreflexia & 1.373 & $0.499-3.777$ \\
\hline Intestinal disorders & 1.261 & $0.756-2.105$ \\
\hline
\end{tabular}

Source: Direct Search. João Pessoa/PB, 2014. ${ }^{*} R R=$ Relative risk; $I C=$ Confidence interval 


\section{Discussion}

In this study, the sociodemographic characteristics of the respondents resembles the scenario described by other researchers, mainly males and individuals in the economically active age group [2, 4, 15-19]. The results also point to correlation of lumbar spinal cord injury to accidents caused by firearms, of chest injury to car accidents and cervical injuries caused by diving in shallow water. Regarding the complications, it is noted that quadriplegia had greater influence as a risk factor for pressure ulcer, spasticity, orthostatic hypotension, urinary complications, autonomic dysreflexia and intestinal disorders, in relation to paraplegia, but showed a protective factor with respect to pain syndromes.

Although there is disagreement about which one is the main cause of spinal cord trauma - trafficaccidents or firearms -, it is correct to say that both are configured as relevant sources of this trauma $[2,6,20]$. The level of spinal cord injury is related to the etiology of trauma, thus it can be explained according to the shock kinematics and biomechanics. The use of biomechanics has an important role in the knowledge of the trauma mechanism, nevertheless it predicts the kind of injury and gravity the victim presents [21].

Traumas related to the spine are usually of great energy and may result in immediate risk to life and evolve with high morbidity and mortality. In this study, through the analysis of correspondence in two-dimensional plane, we can observe a direct relation between the accidents by firearms with lumbar trauma, car accidents with chest injuries and diving with cervical lesions (Figure 1).

Epidemiological studies on TRM point the thoracic and thoracolumbar as the segments most affected by trauma in car accidents. These segments are more susceptible to injury due to the abrupt change of the fixed segment, between the rib cage and the lumbar spine. Thus, when movements occur beyond physiological limits, the injury occurs most easily in this segment $[2,5,22]$.
Still concerning traffic accidents, we emphasize the targeted epidemiological significance to its preventable condition, when obeying traffic laws, improving signposting of roads and using protective measures and required equipment, such as seat belts, helmet, among others. In this context, the study carried out by Vasconcelos and Riberto [4] shows the need to further invest in awareness of the importance of respecting traffic laws, including mandatory use of such equipment.

As for accidents with firearms, it is postulated that the kinematics of trauma involves kinetic energy transfer to the spinal cord, with disruption of axons, nerve cell damage and rupture of blood vessels that cause the primary spinal cord injury and, in the acute stage, followed by hemorrhage and necrosis of the gray matter. The physical separation of the spinal cord tract typically does not occur in non-penetrating trauma, while in the perforating trauma, the most common mechanism is the cord laceration [23-24].

The traumas posed by firearms are mostly associated with urban, public or domestic violence. Thus, it is configured for scoring a young and economically active population, further aggravating the costly impact on public health.

When the etiology of the trauma was diving in shallow water, this study has found its correspondence with the lesions in the cervical region, and these findings were shared by other researchers [25]. The authors also suggest changes in public policies, especially in urban areas, with education and prevention for falls from height campaigns, caution diving in shallow water and automobile and motorcycle accidents, in order to reduce cases of TRM.

Concerning correlations between the causes of trauma and the types of sequel generates by these causes, correspondences were observed between accidents by firearms and paraplegia (complete and incomplete), traffic accidents and the complete paraplegia, and accidents by diving and tetraplegia (Figure 2). As mentioned previously, the kinematics of 
the trauma is reflected at the level of the lesion and kind of sequel. Thus, we point out that as thoracic and cervical segments appear as the most committed, they refer to the greater risk of paraplegia and tetraplegia, respectively. Other studies corroborate with this $[25,5]$ aspect, as well as the definitions of American Spine Injury Association for the neurological classification of TRM [3].

The above data are important because they predict which complications are more likely to occur, providing support in relation to the therapeutic needs and targeted preventive care to these patients. This research highlights as TRM complications the urinary disorders, pressure ulcer, spasticity and pain syndrome and intestinal disorders (Table 1). Other studies corroborate with the findings, describing those mentioned above as the main complications [1,26 -29], although other problems such as pulmonary disorders, are enough referenced as a major complication in these patients [2].

The severity of spinal cord injury is directly related to the type of sequel presented by the individual suffering trauma, and that gravity is increased from the initial level of neurological damage, considered as the most important predictors of neurological outcome of patients. Since the higher this is, the greater the severity. The clinical characteristics, related to the neurological examination, the demographic characteristics and the etiology of injury, help to define more accurately the profile of each individual for the recovery and survival [30].

Considering the connection between the complications found in the sample and the type of sequel (paraplegic/quadriplegic), it was observed that quadriplegia was associated with higher relative risk of developing complications (pressure ulcer, spasticity, orthostatic hypotension, urinary complications, autonomic dysreflexia and intestinal disorders), while it was presented as a protective factor for pain syndromes compared to cases of paraplegia (Table 2).

Secondary clinical complications to TRM are influenced by demographic factors and characteristics related to injury. In0 this context, it is observed that the syndromic of quadriplegia, and ASIA-A neurological status (complete lesion), increase the risk of morbidity and mortality [2].

Concerning the protection factor for pain syndromes, observed by tetraplegic in this study, in relation to paraplegia, it is embodied that this complication is common among individuals with TRM, and may be classified as musculoskeletal or visceral neuropathic, which may be related to neuro-spasticity phenomena, tissue inflammation or visceral onsets [31-32]. In this context, the intensity of pain refers to disabilities, often more emphatic than the loss of functionality. In this regard, studies show in their results that the pain intensity average was higher among individuals with paraplegia when compared with those with tetraplegia [33-34], which corroborates the findings of this study.

\section{Conclusion}

In this study, the sociodemographic and clinical profile of people with TRM presented predominance of male, in the younger age groups economically active, with chest and back injuries resulting from automobile accidents, followed by firearms. Concerning the established correlations, it was observed that traffic accidents and firearm were related to thoracic and lumbar injuries, respectively, and complete/incomplete paraplegia. The main complications were urinary, followed by the UPP and spasticity. Among the listed, quadriplegia was presented as risk to all of them, with the exception of pain syndromes. That said, it is embodied in the scope of the proposed objectives.

Given this research, we understand the vehement need for compulsory notification in Brazil so that, through the records, it will be possible to understand the degree of severity of the injury and its physical, psychological and social impact on affected people, as well as the economic impact for the nation. The absence of notification is a limiting fac- 
tor for the research and construction of new public policies aimed at prevention of determinant external causes of TRM, as well as elaborate actions directed to the specialized care to minimize complications and improve quality of life. The trauma kinematics approach highlights the importance of this understanding for the most insightful performance of Healthcare staff.

The access to people with TRM, because of the lack of their registration in the public health system, was a limiting factor to the study.

Nursing as a science responsible for the direct care by health education and rehabilitation potential, should improve and develop studies that further deepen this theme and which point new perspectives of care for people with TRM.

\section{List of abbreviations:}

PU: Pressure Ulcer

SPSS: Statistical Package for Social Science

HULW: University Hospital Lauro Wan $\neg$ derley

CAAE: Certificate of Presentation for Ethical Consideration

RR: Relative Risk

IC: Confidence interval.

\section{References}

1. Ministério da Saúde. Secretaria de Atenção à Saúde. Diretrizes de Atenção à Pessoa com Lesão Medular. Brasília: Ministério da Saúde; 2015.

2. Morais DF, Spotti AR,Cohen MI, Mussi SE; Melo Neto JS, Tognola WA. Perfil epidemiológico de pacientes com traumatismo raquimedular atendidos em hospital terciário. Coluna/Columna [Internet]. 2013 [cited 2016 mar 20]; 12(2):149152 Available from: http://www.scielo.br/scielo.php?script=sci arttext\&pid=S1808-18512013000200012\&lng=en\&nrm=iso

3. American Spinal Injury Association (ASIA). International Standards for Neurological Classification of SCI (ISNCSCI) [Internet]. 2015. Disponível em: http://www.asia-spinalinjury. org/elearning/isncsci worksheet 2015 web.pdf
4. Vasconcelos ECLM, Riberto M. Caracterização clínica e das situações de fratura da coluna vertebral no município de ribeirão preto, propostas para um programa de prevenção do trauma raquimedular. Coluna/Columna [Internet]. 2011[cited 2016 abr 15]; 10(1):40-3 Available from: http://www.scielo.br/scielo. php? script=sci arttext \&pid=S1808-18512011000100007

5. Brito LMO, Chein MBC, Marinho SC; Duarte TB. Avaliação epidemiológica dos pacientes vítimas de traumatismo raquimedular. Rev. Col. Bras. Cir [Internet]. 2011 [cited 2016 mai 09]; 38(5):304-9, Available from: http://www.scielo.br/scielo. php?script=sci_arttext\&pid=S0100-69912011000500004\&lng =en\&nrm=iso

6. Devivo MJ. Epidemiology of traumatic spinal cord injury: trends and future implications. Spinal Cord. [Internet]. 2012 [cited] 2016 abr 20]; 50 (5):365-72. Available from: https://www. researchgate.net/publication/221770873

7. Viúdes MAA, Costa JM, Perez CM. Perfil dos pacientes internados por trauma raquimedular em hospital público de ensino. Rev. méd. [Internet]. 2015 [cited] 2016 abr 16]; 25(3):380-06. http://www.rmmg.org/artigo/detalhes/1815

8. Gotfryd AO, Franzin FJ, Poletto PR, Carneiro Neto NJ, Nogueira Júnior RC, Ferreira Júnior LCL. Fracture-dislocation of the thoracic spine during second trimester of pregnancy: case report and literature. Rev Bras Ortop. [Internet]. 2012 [cited 2015 Nov 21]; 47(4):521-5. Avaliable from: http://www.scielo.br/ scielo.php?script=sci arttext\&pid=S0102-36162012000400021

9. Brasil. Instituto Brasileiro de Geografia e Estatística. IBGE [Internet]. 2014 [citado 2014 Dez 15]. Disponível em: http://cidades.ibge.gov.br/xtras/perfil.php?codmun=250750

10. American Spinal Injury Association (ASIA). International Standards for Neurological Classification of SCI (ISNCSCI) [Internet]. 2013. Disponível em: http://www.asia-spinalinjury. org/elearning/isncsci worksheet 2015 web.pdf

11. Sociedade Brasileira de Urologia. Projeto Recomendações. 2013.

12. Ministério da Saúde. Secretaria de Atenção à Saúde. Diretrizes de Atenção à Pessoa com Lesão Medular. Brasília: Ministério da Saúde; 2013.

13. Motta WT. Bioestatística. $2^{\mathrm{a}}$ ed. Caxias do Sul: Educs; 2006.

14. Brasil. Resolução $n^{\circ} 466$, de 12 de dezembro de 2012. Dispõe sobre diretrizes e normas regulamentadoras de pesquisas envolvendo seres humanos. Diário Oficial da República Federativa do Brasil. Brasília: Ministério da Saúde; 2012.

15. Feng HY, Ning GZ, Feng SQ, Yu TQ, Zhou HX. Epidemiological profile of 239 traumaticspinal cord injury cases over a period of 12 year in Tianjin, China. J Spinal Cord Med. 2011; 34(4): 38894.

16. Soares RAS, Diniz IV, Nascimento JA, Soares MJGO. Caracterização dos acidentes de trânsito que apresentaram como desfecho trauma raquimedular. Rev enferm UFPE on line [Internet]. 2013 [cited 2016 jan 23]; 7(10):5996-6005. Available from: file:///C:/Users/Karen/Downloads/4425-47708-1-PB.pdf 
17. Wu Q, Li YL, Ning GZ, Feng SQ, Chu TC, Li Y, et al. Epidemiology of traumatic cervical spinal cord injury in Tianjin, China. Spinal Cord. 2012 Oct; 50(10):740-4.

18. Wang H, Xiang Q, Li C, Zhou Y. Epidemiology of traumatic cervical spinal fractures and risk factors for traumatic cervical spinal cord injury in China. J Spinal Disord Tech. 2013 Dec; 26(8):E306-13

19. Dhamangaonkar AC, Joshi $D$, Kumar R, Goregaonkar $A B$. Patients with blunt traumatic spine injuries with neurological deficits presenting to an urban tertiary care centre in mumbai: an epidemiological study. Malays Orthop J. 2013 Mar; 7(1):3640.

20. Gonçalves $A M T$, Rosa $L N$, D'Ângelo $C T$, Savordelli $C L$, Bonin $G L$, Squarcino IM, et al. Aspectos epidemiológicos da lesão medular na área de referência do Hospital Estadual Mário Covas. Arq Med ABC. 2007; 32(2):64-6.

21. Fernandes TPR. A cinemática do trauma como ferramenta para a atuação para enfermeiro de emergência. Enfermagem atual. 2007; 7(37): 15-8.

22. Zaninelli EM, GraellsXSI, Néri OJ, Dau L. Avaliação epidemiológica das fraturas da coluna torácica e lombar d epacientes atendidos no pronto-socorro do Hospital do Trabalhador da UFPR de Curitiba - Paraná. Coluna/Columna. 2005;4(1):11-5.

23. Araújo Junior FA, Heinrich $C B$, Cunha MLV, Veríssimo DCA, Rehder $\mathrm{R}$, Pinto CAS, et al. Traumatismo raquimedular por ferimento de projétil de arma de fogo: avaliação epidemiológica. Coluna/Columna [Internet]. 2011 [cited 2016 May 06]; 10 (4): 2902. Available from: http://www.scielo.br/scielo.php?script=sci arttext\&pid=S1808-18512011000400008\&lng=en.

24. Costa RC, Caliri MHL, Costa LS, Gamba MA. Fatores Associados á Ocorrência de Úlcera Por Pressão em Lesados Medulares. Rev Neurocienc 2013; 21(1): 60-8.

25. Fernandes RB, Gomes EGF, Gusmão MS, Amorim Júnior DC, Simões MTV, Gomes JF, et al. Estudo clínico epidemiológico das fraturas da coluna vertebral. Coluna/Columna [Internet]. 2012 Sep [cited 2016 May 06]; 11( 3 ): 230-3. Available from: http://www.scielo.br/scielo.php?script=sci_arttext\&pid=S180818512012000300009\&lng=en

26. Pereira CU, Carvalho LFP, Santos EAS. Complicações clínicas do traumatismo raquimedular: pulmonares, cardiovasculares, geniturinárias e gastrointestinais. Arq Bras Neurocir 2010;29(3): $110-7$.

27. Sousa EPD, Araújo OF, Sousa CLM, Muniz MV, Oliveira IR, Neto NGF. Principais complicações do Traumatismo Raquimedular nos pacientes internados na unidade de neurocirurgia do Hospital de Base do Distrito Federal. Com. Ciências Saúde. 2013; 24(4): 321-30.

28. Yang R, Guo L, Wang P, Huang L, Tang Y, Wang W, et al. Epidemiology of Spinal Cord Injuries and Risk Factors for Complete Injuries in Guangdong, China: A Retrospective Study. PLoS One. 2014; 9(1): e84733.
29. Scopel G, Jacob Júnior C, Brazolino MAN, Cardoso IM, Batista Júnior JL, Sogame LC, et al. Avaliação do perfil epidemiológico do lesado medular traumático de um serviço de coluna do estado do Espírito Santo. Arq Bras Neurocir. sep; 2015; 1(1).

30. Wilson JR, Cadote DW, Fehlings MG. Clinical predictors of neurological outcome, functional status, and survival after traumatic spinal cord injury: a systematic review. J Neurosurg Spine. 2012 Sep; 17(1 Suppl):11-26.

31. Fornasari D. Pain mechanisms in patients with chronic pain. Clin Drug Investig. 2012; 32 Suppl 1:45-52. 24.

32. Vall J, Costa CMC, Santos TJT, Costa SBC. Neuropathic pain characteristics in patients from Curitiba (Brazil) with spinal cord injury. Arq Neuropsiq. 2011;69(1):64-8.

33. Ullrich PM, Jensen MP, Loeser JD, Cardenas DD. Pain intensity, pain interference and characteristics of spinal cord injury. Spinal Cord. 2008; 46 (6): 451-5.

34. Rodrigues AV, Vidal WAS, Lemes JA, Gôngora CS, Neves TC, Santos SMS, et al. Estudo sobre as características da dor em pacientes com lesão medular. Acta Fisiátr. 2012; 19(3): 171-7.
Publish in International Archives of Medicine

International Archives of Medicine is an open access journal publishing articles encompassing all aspects of medical science and clinical practice. IAM is considered a megajournal with independent sections on all areas of medicine. IAM is a really international journal with authors and board members from all around the world. The journal is widely indexed and classified Q1 in category Medicine. 